27

\title{
PARAMETERS AFFECTING ENZYME-ASSISTED AQUEOUS EXTRACTION OF EXTRUDED SUNFLOWER MEAL
}

\author{
Kerry A. Campbell ${ }^{\mathrm{a}, \mathrm{b}}$, Guadalupe Vaca-Medina,, Charles E. Glatz ${ }^{\mathrm{a}}$, Pierre-Yves \\ Pontalier ${ }^{c, *}$ \\ ${ }^{a}$ Department of Chemical and Biological Engineering, Iowa State University \\ ${ }^{\mathrm{b}}$ The Solae Company, 4272 S Mendenhall Rd. Memphis, TN 38141 \\ ${ }^{\mathrm{c}}$ Laboratoire de Chimie Agro-industrielle (LCA), Université de Toulouse, INRA, INPT, \\ Toulouse, France
}




\section{ABSTRACT}

Microscopic observation of sunflower meal before and after extraction indicated that

31 extensive cellular disruption was achieved by extrusion, but that unextracted oil remained

32 sequestered as coalesced oil within the void spaces of disrupted cotyledon cells. A full factorial

33 design experiment was defined to develop aqueous extraction processing (AEP) with and without

34 enzymes to improve vegetable oil extraction yields of extruded sunflower meal. This

35 experimental design studied the influence of four parameters, agitation, Liquid/solid (L/S) ratio,

36 and cellulase and protease addition, on extraction yield of lipid and protein. Agitation and

37 addition of cellulases increased oil extraction yield, indicating that emulsification of oil and

38 alteration of the geometry of the confining cellular matrix were important mechanisms for

39 improving yields. Protease and liquid- solid ratio of the extraction mixture did not have

40 significant effects, indicating key differences with previously established soy oil extraction

41 mechanisms. Maximum yields attained for oil and protein extraction were 39\% and 90\%,

42 respectively, with the aid of a surfactant.

43

44

45 Key words: aqueous extraction, protease, cellulase, oil, sunflower, enzymes 


\section{$47 \quad$ 1. Introduction}

Pressing, with single screw extruders, is usually the first step of oil production. For seeds with high oil content such as sunflower, extraction yields of $70 \%$ to $85 \%$ can be achieved

50 (Kartika, Pontalier \& Rigal, 2006; Evon, 2008). However, to maximize yields, residual oil in the

51 extruded meal is extracted with an organic solvent, most commonly hexane. An important part of

52 the Green Chemistry (Anastas \& Warner, 1998) movement is to develop technologies that are

53 environmentally friendly and reduce the use of petroleum-derived materials. Aqueous extraction

54 processing (AEP) and enzyme-assisted aqueous extraction processing (EAEP) are safe water-

55 based extraction processes that, with the use of enzymes, have succeeded in achieving free oil 56 yields as high as $88 \%$ in soybean oil extraction (Moura, Campbell, Mahfuz, Jung, Glatz \& 57 Johnson, 2008, Moura \& Johnson, 2009).

In an immiscible oil-water system, the ability to extract oil is dependent on its mobility 59 within the solid matrix confining the unextracted portion (Campbell \& Glatz, 2009). Therefore,

60

61

62

63

64 65

one important factor in AEP/EAEP is the geometry of the confining matrix as determined by the nature of the oilseed itself, as well as the mode of comminution used to disrupt cells. In soy, grinding and extruding produced substrates with very different physical geometries from which the oil must escape (Campbell \& Glatz, 2009). In the case of extrusion, oil was released from a matrix of insoluble denatured protein, while in flour from flakes; oil was released from partially disrupted cells.

Cellulases increase the extraction yield of oil from ground sunflower in EAEP by cellular disruption (Dominguez, Nunez \& Lema, 1995; Sineiro, Dominguez, Nunez \& Lema, 1998) but could also act by modifying the geometry of cells previously disrupted, thus facilitating oil 
transfer out of the remaining matrix. Furthermore, Campbell and Glatz have established that

70 emulsification is a key parameter in the extraction mechanism for EAEP of soybean flour

71 (Campbell \& Glatz, 2009). In an aqueous environment, where the extract (oil) is immiscible with

72 the solvent (water), extraction is increased when coalesced oil entrapped within ruptured cells

73 can be emulsified into smaller, more mobile droplets by turbulent forces in the extraction

74 medium.

75 Another important factor for soy oil extraction is the nature of the oil-water interface.

76 Campbell and Glatz proposed that the mechanism, by which protease increases oil yields in soy

77 flour extraction, is by disruption of a viscoelastic interfacial protein film at the oil-water

78 interface, facilitating emulsification. Badr and Sitohy demonstrated that at $\mathrm{pH} 5$ proteases can

79 also increase the yields of sunflower oil from dehulled chopped seeds, which they attributed to a 80 disruption of lipid-protein complexes (Bair \& Snyder, 1980).

81

The objectives of this work were to identify the conditions to increase the oil recovery

83 yield from extruded meal, using aqueous extraction or enzyme-assisted aqueous extraction

84 instead of the classical hexane extraction procedure.

85

86 2. Materials and methods

\subsection{Preparation of Extruded Sunflower Meal}

89 France) were extruded in an Omega 20 single screw bench top press-extruder (Eurl Laplace Co.,

90 Pau, France), equipped with a heated collar around the die housing. Steady-state exit temperature

91 of the extruded cake was measured to be around $100{ }^{\circ} \mathrm{C}\left(+/-5^{\circ} \mathrm{C}\right)$ with an infrared thermometer. 
92 Expressed oil was collected, weighed, and centrifuged. The resulting precipitate was rinsed three

93 times with cylcohexane, dried, and weighed to determine the fraction of foots in the expressed

94 oil. The resulting cake was cooled and then ground in a Pulverisette 19 (Fritsch Ltd. Idar-

95 Obersteen, Germany) knife mill with a $2 \mathrm{~mm}$ outlet screen. Extruded meal was stored at $-20{ }^{\circ} \mathrm{C}$

96 until use.

\subsection{Extraction}

The appropriate quantity of extruded meal was added to $1 \mathrm{~L}$ of DI water in a $2 \mathrm{~L}$ jacketed

99 reactor with an agitator, maintained at $50{ }^{\circ} \mathrm{C}$ with a water bath and at constant $\mathrm{pH} 6.5 \mathrm{using}$ a 716 DMS Titrino autotitrator (Metrohm Ltd., Herisau, Switzerland) with 1 N NaOH. Samples were collected by siphon into a $500 \mathrm{~mL}$ bottle, weighed, and centrifuged (Sigma 6-16k) at 3000g

102 for $15 \mathrm{~min}$ at $20^{\circ} \mathrm{C}$. The supernatant was discarded and the remaining residual solid was

103 weighed, freeze dried, and weighed again for moisture determination. Freeze-dried precipitate 104 was ground in a coffee grinder for approximately $30 \mathrm{~s}$ and then stored in a dessicator until oil and 105 protein content determination. Yield was calculated as one minus the fraction of total material 106 remaining in the residual fraction. Protein dissolution was defined as the protein extraction yield 107 plus the fraction of dissolved protein entrained in the solid-fraction, estimated by multiplying the 108 liquid fraction protein concentration by the mass of water in the solid fraction. The liquid 109 fraction protein content was determined by mass balance based on the protein content of the 110 residual fraction.

For microscopy experiments, extraction was carried out by placing extruded meal in 500 $112 \mathrm{~mL}$ centrifuge bottles with DI water for a solid-liquid ratio of 1:10. Bottles were placed on a stir 113 plate in a water bath maintained at $50{ }^{\circ} \mathrm{C}$, and agitated with a magnetic stir bar at $1000 \mathrm{rpm}$.

114 Centrifugation $\left(3000 \mathrm{~g} 15 \mathrm{~min}\right.$ at $20^{\circ} \mathrm{C}$ ) resulted in two distinct layers in the centrifuge bottles. 
115 Therefore, samples for microscopy were from the bulk mixture before centrifugation and from 116 each of the two layers after centrifugation.

\subsection{Full Factorial Design Experiment}

118 To elucidate the effects of enzyme, solid-liquid ratio, and agitation, a randomized full factorial 119 design experiment was conducted using two continuous two-level parameters: solid-liquid ratio 120 (0.05 and 0.10) and agitation rate (160 and $350 \mathrm{rpm})$, plus two discrete parameters: with and 121 without protease Protex 7L and with and without cellulase Multifect CX 13L, kindly provided by

122 Genencor (Rochester, NY), both $2 \%$ w/w solid, giving a total of 16 possible experimental 123 conditions. Cellulase Multifect CX 13L, with a specific activity of 3,900 CMC/g, exhibits 124 significant activity towards cellulose, hemicelluloses, $\beta$-glucans and arabinoxylans. The Protex 7L (also named Multifect Neutral) has an activity of 1600 AU (Azo Unit)/g define by hydrolysis 126 of Azo-casein substrate at $\mathrm{pH} 7.5$ for 5 minutes at $30^{\circ} \mathrm{C}$. The active $\mathrm{pH}$ ranges of these enzymes 127 overlap in the $\mathrm{pH} 6$ to 7 region, and so $\mathrm{pH} 6.5$ was selected for all of these experiments.

128 Measured responses were oil extraction yield, protein dissolution, and non-lipid material 129 dissolution. Trials for the full factorial design experiment were not replicated, while all other trials reported were made in triplicate. Error estimation for analysis of variance (carried out using 131 JMP 7 software from SAS Institute, Inc. Cary, NC) was based on the assumption of interactions 132 of an order higher than two, being nonsignificant.

\subsection{Analytical Methods}

Oil was extracted from residual samples four times for $10 \mathrm{~min}$, at $105{ }^{\circ} \mathrm{C}$ and 95 bar with 135 cyclohexane using an ASE 200 Accelerated Solvent Extractor (Dionex Corp, Sunnyvale, CA). 136 Extract was transferred from vials to preweighed glass beakers (dried $1 \mathrm{~h}$ at $103{ }^{\circ} \mathrm{C}$, cooled to 137 room temperature on the bench top), rinsing twice with cyclohexane. Cyclohexane was 
evaporated by placing beakers in a boiling water bath and then drying them for $1 \mathrm{~h}$ in a $103{ }^{\circ} \mathrm{C}$ oven. Beakers were cooled to room temperature on the bench top, and weighed again to determine mass of oil. Protein content was determined by the Kjeldahl total nitrogen method using a nitrogen to protein conversion factor of $6.25 \mathrm{~g}$ protein per $\mathrm{g}$ nitrogen. Residual moisture content was determined by loss of mass upon freeze-drying. Moisture gained during sample storage was analyzed simultaneously with oil content determination, by measuring the loss of mass upon drying samples at $103{ }^{\circ} \mathrm{C}$ for $24 \mathrm{~h}$. This was used to correct the oil content determination.

\subsection{Particle Size Distribution of Extruded Meal}

Particle size distribution of extruded meal was determined by sieving. $250 \mathrm{~g}$ of extruded meal was placed in a sieve-shaker equipped with four different sieve sizes: $1.25 \mathrm{~mm}, 0.80 \mathrm{~mm}$, $0.50 \mathrm{~mm}$, and $0.25 \mathrm{~mm}$. Material was fractionated for $15 \mathrm{~min}$ at a frequency of $50 \mathrm{~s}^{-1}$, and then weighed from each screen. As the entire meal was used for the experiments, specific extrusions were done for particle size distribution determination.

\subsection{Differential Scanning Calorimetry (DSC)}

The extent of protein denaturation was determined by measuring the heat absorbed by 12 $\mathrm{mg}$ samples of dry material, heated at a rate of $10^{\circ} \mathrm{C}$ per minute from room temperature to $190^{\circ} \mathrm{C}$ using a Pyris 1 differential scanning calorimeter (Perkin Elmer, Waltham, MA).

\subsection{Microscopy}

Samples were fixed and embedded following Bair and Snyder (Boy \& Snyder, 1980) with minor modifications, at the Centre de Microscopie Electronique Appliquée in Toulouse, France. Sections were made at the Iowa State University NanoImaging Facility using a Reichert Ultracut S ultramicrotome (Leeds Precision Instruments, Minneapolis, MN). Thick sections 
161 were contrast stained using $1 \%$ toluidine blue. Light microscopy images were made using a Zeiss Axioplan 2 light microscope (Carl Zeiss MicroImaging, Inc., Thornwood, NY).

\section{Results and discussion}

\subsection{Extruded meal characterization}

Sunflower kernels were extruded at bench scale with a single screw press-extruder. The moisture, $20.6 \%(+/-0.1)$ oil (dry basis), and 30.1\% (+/- 0.4) protein (dry basis). Based on the extrusion was $44 \%$ and oil extraction yield was $68 \%$.

The mass-weighted particle size distribution profile of the extruded meal has been

172 determined (data not shown). The only fraction where hulls were not clearly visible was the 173 smallest one, $<0.25 \mathrm{~mm}$. The largest fraction appeared to be mostly hulls, with the other fractions 174 containing a mix of seed particles and hull. The high oil content of the extruded meal caused 175 considerable clumping, making sieve separation ineffective for the smaller particle size ranges.

179 length, and 20 to $40 \mu \mathrm{m}$ in diameter while protein bodies' ranged from 1 to $10 \mu \mathrm{m}$ in diameter.

180 The protein bodies filled a smaller proportion of the cytoplasmic volume compared to soy 181 protein bodies (Bair \& Snyder, 1980; Mantese, Medan \& Hall, 2006). Oil bodies, that is oil 182 storage organelles delimited by a protein-phospholipid membrane, occupied the space between 183 protein bodies. 
After extrusion, intact cotyledon cells were not observed (Figure 1b). Regions of disrupted cotyledon cells, with few recognizable structures, are seen between regions of intact sclerenchyma cells, the hollow structural and vascular tissue making up the bulk of the sunflower pericarp (Mantese et al., 2006). Some disrupted cell wall material can be seen on the outer regions of the disrupted cotyledon tissue (images not shown). Lipid was observed mostly as coalesced oil, in the outer regions of the extruded cellular matrix inside and outside disrupted cells. No intact oil bodies are visible. Some lipid is also observed in the interior of sclerenchyma cells of the pericarp. Sunflower pericarp is low in lipids (generally less than 5\%) and it is unlikely that the lipid observed here occurs in vivo. A likely explanation for this observation is that the heat and pressure during extrusion causes some oil to fill the void spaces in the sclerenchyma cells.

After centrifugation, residual material settled into two distinct layers in the centrifuge bottles: a lower coarse layer making up about $80 \%$ of residual volume, and an upper layer of fine gray material making up the remainder. The lower layer consisted of a mixture of pericarp and disrupted cotyledon tissue, while the upper layer contained only cotyledon cells with some seed coat particles (Figure 2). As before, no intact cotyledon cells were observed; all cells have undergone at least some extraction of the cytoplasmic material but oil remains in some cells as coalesced oil droplets. Furthermore, coalesced oil is again prominent in sclerenchyma cells. These results are similar to those observed in soybean, where unextracted oil is sequestered inside disrupted cells as coalesced droplets too large to pass out of the matrix (Campbell \& Glatz, 2009). A notable difference from soybean, however, is the entrapment of oil in the void spaces of the pericarp sclerenchyma cells. 
The extent of protein denaturation and solubility has a crucial influence on the oil yield $22785 \%$. with aqueous extraction in soybeans (Rosenthal, Pyle, Niranjan, Gilmore \& Trinca, 2001; Campbell \& Glatz, 2009). Therefore, the conformational state of sunflower protein in the extrudate was analyzed, and compared to a control sample of pressed, ground sunflower seeds which had not been exposed to the heat of extrusion. The heat absorption profile of the extrudate is shown in Figure 3. An obvious peak occurs at $150{ }^{\circ} \mathrm{C}$, which is slightly lower than the $155{ }^{\circ} \mathrm{C}$ denaturation temperature determined by Rouilly et al. (2003) for untreated sunflower of similar moisture content (10\%). The peak area divided by the protein content of the samples, both extruded and pressed, gives a specific heat of denaturation of $9.7(+/-0.4) \mathrm{J} / \mathrm{g}$ protein. By comparison, Rouilly et al. report denaturation enthalpies of $8.6 \mathrm{~J} / \mathrm{g}$ protein. Therefore, the extrusion conditions used here did not affect the conformational state of the sunflower proteins (Rouilly, Orliac, Silvestre, Rigal, 2003).

\subsection{Aqueous extraction and enzyme assisted aqueous extraction}

\subsubsection{Full Factorial Design Experiment results}

The measured responses for oil extraction yield, protein dissolution, and non-lipid material dissolution are shown in Table 1. The results indicate that in aqueous extraction conditions (trial 6, 7, 12 and 13) this is about 30\% for oil (with the exception of Trial 12), comparable to similar extraction conditions from Bayberry (Zhang, Li, Yin, et al. 2012), 56\% for proteins and $27 \%$ for the others. The highest recovery yields are obtained when extraction is managed with both enzymes, with an oil recovery yield of $40 \%$ and a protein recovery yield of

Significant parameters were identified by ANOVA. Table 2 summarizes the parameter estimates determined after elimination of the insignificant terms, the resulting analysis of 
230 variance, and statistical significance. For oil extraction yield, only agitation and cellulase had

231 significant main effects, while solid to liquid ratio and protease had significant interaction

232 effects. Dissolution of non-lipid material, on the other hand, was not affected by agitation at all,

233 with protease having the most important effect. The effect of cellulase was also significant, but

234 the increase in dissolution caused by cellulase was much smaller than that of protease. Only

235 protease had a significant effect on protein dissolution with an average increase of $28 \%$. The

236 goodness of fit and significance for the three responses after elimination of the insignificant

237 parameters, are shown in Figure 4. Each of the models fit the data well, with actual values

238 plotted against predicted values randomly distributed around a line of a slope of one on the fit

239 test plot. The p-values for all models were less than 0.02 .

240

241

242

243

244

245

246

247

248

249

250

251

252

\subsubsection{Influence of parameters}

Sunflower protein from defatted meal generally has low nitrogen solubility, less

than $30 \%$ at $\mathrm{pH} 6.5$ and low ionic strength, but this increases with salt addition (Kabirullah \& Mills, 1983; Canella, Castriotta, Bernardi \& Boni, 1985) and hydrolysis (Kabirullah \& Mills, 1981). A protein solubilization of $85 \%$ with protease indicates a very high degree of disruption. Assuming protein can only be extracted from disrupted cells, as has been previously established (Campbell \& Glatz, 2009), at most $15 \%$ of the cells remained intact after extrusion, and it could be even less considering the low solubility of sunflower proteins under these conditions.

Cellulase addition was made to facilitate the oil's exit from the solid residue, by promoting disruption of cells that were still intact after extraction and by promoting the modification of the disrupted structures. Comparisons between the significant parameters, for the

three different responses, indicate that cellulases affected both oil extraction yield (3\%) and 
253 dissolution of non-lipid material, but not dissolution of protein. Cellulose degradation occurs but

254 was limited and did not change the dissolution and the transfer of the entrapped molecules. As no 255 intact sunflower cotyledon cells were observed in microscopic images of extruded sunflower 256 meal, one possible explanation could be that extrusion succeeded in achieving near complete 257 cellular disruption prior to extraction. There are no noticeable differences in these images 258 between material extracted with and without cellulase. Nonetheless, the entrapment of oil 259 droplets inside the confines of the cell wall of disrupted cells, suggests that the effect of cellulase 260 is to disrupt this confining matrix.

Agitation can increase oil yield through several physical mechanisms depending on its 262 intensity, and at the highest levels it can increase oil release by rupturing intact cells. The shear 263 and turbulence created by agitation can also break up the solid matrices that entrap oil within the 264 confines of disrupted cells. A third possibility is that the turbulence of agitation increases the 265 emulsification of oil within the cells, creating smaller oil droplets that exit more efficiently out of 266 the cellular matrix into the bulk fluid. Since agitation did not affect dissolution of protein or 267 other non-lipid material, it is unlikely that it caused significant additional cell rupture, since 268 extrusion alone achieved a high degree of cellular disruption as indicated by microscopic 269 observation. Consequently, as increasing agitation from $160 \mathrm{rpm}$ to $350 \mathrm{rpm}$ increased oil 270 extraction yields by an average of $8 \%$, it can be assumed that this effect comes from 271 modification of the droplet sizes.

272 Campbell and Glatz (2009) showed that emulsification is an important extraction 273 mechanism for AEP of soybean oil. To illustrate the level of droplet disruption that can be 274 achieved in the given mixing system a turbulent inertial droplet breakup model from Vankova et 275 al. has been used to estimate the maximum stable droplet diameter of oil in AEP of soybeans 
276 (Vankova, Tcholakova, Denkov, Ivanov \& Vulchev, 2007; Campbell \& Glatz, 2009). According

277 to this model and the agitator power number, the maximum stable droplet diameter would be in

278 the range of 15 to $20 \mu \mathrm{m}$ for the $160 \mathrm{rpm}$ condition and 3 to $5 \mu \mathrm{m}$ for the $360 \mathrm{rpm}$ condition,

279 assuming no viscoelastic protein film at the interface, and an interfacial surface tension of 5

$280 \mathrm{mN} / \mathrm{m}$, as measured for soy protein-oil systems (Campbell \& Glatz, 2009).

281

Experiments designed to alter the oil-water interfacial conditions during extraction,

confirm the influence of the droplet structure on oil recovery yield. The addition of $3 \%(\mathrm{w} / \mathrm{w}$

solid) sodium dodecyl sulfate (SDS) increased the extraction yield of oil from $28.4 \%(+/-1.4)$ to

284

$39.0 \%(+/-0.6)$ at $160 \mathrm{rpm}, \mathrm{S} / \mathrm{L}=0.10(+/-95 \%$ confidence interval, $\mathrm{n}=3)$. At the same time,

285 protein extraction increased from $57 \%(+/-1)$ to $90 \%(+/-2)$, which is even more than the increase with protease, which was $86.2 \%(+/-0.1)$. The addition of protease increased protein extraction almost as much as SDS addition, but protease had no effect on oil extraction yield.

\subsection{Extraction model}

The mechanism of protease action for oil yield enhancement in AEP of soybean is due to alteration of the oil-water interface by two possible mechanisms: 1) disruption of a viscoelastic protein film, or 2) creation of protein hydrolysates that are better emulsifiers than native proteins (Campbell \& Glatz, 2009; Latif \& Anwar, 2013). The same authors also hypothesized that higher solid-liquid ratios $(\mathrm{S} / \mathrm{L})$ reduced soybean oil extraction by increasing

294 interfacial protein coverage, and therefore viscoelastic effects.

Unlike soybean extraction, neither proteases nor S/L had a measurable effect on oil

297 Sunflower has lower protein content than soy, $30 \%$ compared to $40 \%$ for sunflower extrudate 
to concentrations seen in soybean extractions, ranging from $8 \mathrm{mg} / \mathrm{ml}$ for $\mathrm{S} / \mathrm{L}$ of 0.05 and no 300 protease, to $25 \mathrm{mg} / \mathrm{ml}$ for $\mathrm{S} / \mathrm{L}$ of 0.10 with protease, for sunflower extrudate. For soybean under 301 the same conditions, protein concentrations were $19 \mathrm{mg} / \mathrm{ml}$ and $38 \mathrm{mg} / \mathrm{ml}$, respectively 302 (Campbell \& Glatz, 2009). If the formation of a viscoelastic film impedes oil release in soy, this 303 does not appear to be the case in sunflower, as neither increasing the protein concentration (and, 304 hence, interfacial coverage) nor disrupting a film by hydrolysis, affects yield. This sunflower 305 extrudate result also differs from that found for extraction of dehulled ground sunflower seeds, where S/L did affect oil extraction [1]. However, the ground seeds had much higher oil content $307(>40 \%)$ and were subjected to a larger range of $\mathrm{S} / \mathrm{L}(0.05$ to 0.2$)$ and $\mathrm{pH}$, although the latter had 308 no effect.

If disruption and diffusion of oil droplets were important mechanisms for extraction, 310 a greater oil concentration in the bulk would cause S/L to have a measureable effect. Droplets 311 much smaller than the dimensions of a rupture in a cell wall would be able move into as well as 312 out of disrupted cells. Therefore, the volume of disrupted cells with which the droplets can 313 exchange, relative to the total volume, would affect yield. As relative cell volume increased (i.e. 314 at higher S/L), so would the entrained fraction of oil in those cells, and the amount would be 315 proportional to the concentration of freely exchanging bulk oil droplets. Evon hypothesized that 316 increasing the relative amount of water (i.e. decreasing S/L) increased the amount of oil that 317 could be stabilized in an emulsion, a phenomenon that would also be more apparent in material 318 with higher oil content (Evon, Vandenbossche, Pontalier \& Rigal, 2007; Evon, 2008). Since S/L 319 effects were not observed here, it is possible that the oil concentration in this case was too low to 320 have a measureable effect. 

properties over native soy proteins, this does not appear to be the case for the present sunflower material. In other studies of sunflower protein-stabilized emulsions, hydrolysis of up to $10 \%$ of

325 the peptide bonds did not have an effect on the droplet diameter under conditions similar to those used in these experiments (Karayannidou et al., 2007). Sunflower protein hydrolyzates may not

327 therefore be able to increase yield through enhanced emulsification. chopped, rather than extruded, sunflower seeds (Badr \& Sitohy, 1992). This contrast may be a result of differences in geometry of the matrices entrapping unextracted oil. In order for the turbulent forces to cause droplet breakup, eddies in the medium must be free to impinge on oil 332 droplets, creating local pressure gradients around them. In sunflower extrudate, much oil was observed completely filling the sclerenchyma tissue void spaces, reducing the surface area 334 available for energy transfer between turbulent eddies and oil droplets. The fraction of oil contained within the sclerenchyma tissue, would therefore be a theoretical limit to the amount of extraction that could take place in an aqueous environment without cellulolytic treatment, 337 because of the geometrical barriers against emulsification. extrudate. The results showed that introducing SDS leads to both increased oil and protein yield, 340 while protease only increases protein yield. It could be that oil remained entrapped, after 341 extrusion of sunflower kernel, in large structures involving proteins, and that these were too large 342 to diffuse out of the solid residue. Protease addition could modify these structures, but as the 343 hydrolyzed proteins have low emulsifying properties, only they are recovered while the lipids 344 remain fixed on the residue. SDS addition seems to induce geometry changes in these structures, 
345 allowing solubilisation of protein but also creation of smaller oil droplets that can then diffuse

346 out. Changing the size of these structures can also be achieved with stronger agitation, but this

347 action remains minimal since the oil recovery yield increase is only $3 \%$.

348 The presence of insoluble protein inside the sunflower seed cotyledon cells could pose a 349 major barrier to oil release and would explain this observation, and this insolubility may be 350 caused by the extrusion (Jung, 2009). Hulls can also hinder the extraction because they contain 351 mucilage that reduces the release of oil into the aqueous phase ( Tabtabaei \& Diosady, 2013).

\section{4. Conclusions}

Oil remaining in extruded sunflower meal after AEP/EAEP, was contained as coalesced 354 oil droplets inside disrupted cotyledon cells and in void spaces of pericarp sclerenchyma cells. 355 Agitation and cellulase treatment increased oil extraction yields, but protease and solid liquid 356 ratio did not affect yields, contrary to observations for soybean. While emulsification may be an 357 important extraction mechanism produced by agitation, the geometry of the cellular matrix 358 entrapping coalesced oil may also be an important factor determining extraction yield, and is a 359 possible explanation for the differences between sunflower and soybean oil extraction 360 determination. Based on these observations, the extraction yields from both extrusion as well as 361 AEP/EAEP could be improved if the kernels could be extruded in the absence of hulls.

\section{Acknowledgements}

The authors would like to thank the USDA CREES Grants \#2005-34432-1406 and 2006-

365 34432-17128, the Iowa State University Plant Science Institute, and the US Department of

366 Education Renewable Resources and Clean Technology grant for funding this research. We 
would also like to thank the Centre de Microscopie Electronique Appliquée in Toulouse, France, as well as Tracey Pepper and Randall DenAdel at the NanoImaging Facility at Iowa State University for the microscopy.

\section{REFERENCES}

Anastas, P.T., \& Warner, J.C. (1998). Green chemistry: theory \& practice, New York: Oxford University Press.

Badr, F.H., \& Sitohy, M.Z. (1992). Optimizing conditions for enzymatic extraction of sunflower oil. Grasas Aceites, 43(5), 281-283.

Bair, C.W., \& Snyder, H.E. (1980). Electron-microscopy of soybean lipid bodies. J Am Oil Chem Soc., 57(9), 279-282.

Campbell, K.A., Glatz, C.E. Mechanisms of aqueous extraction of soybean oil. J Ag Food Chem. $2009 ; 57(22): 10904-10912$.

Canella, M., Castriotta, G., Bernardi, A., \& Boni, R. (1985). Functional-properties of individual sunflower albumin and globulin. Lebensm.-Wiss Technol., 18(5), 288-292.

Dominguez, H., Nunez, M.J., \& Lema, J.M. (1995). Aqueous processing of sunflower kernels with enzymatic technology. Food Chem., 53(4), 427-434.

Evon, P. Nouveau Procédé de Bioraffinage du Tournesol Plante Entière par Fractionnment Thermo-mécano-chimique en Extrudeur Bi-vis: Étude de L'Extraction Aqueuse des Lipides et de la Mise en Forme du Raffinat en Agromatériaux par Thermomoulage, [Dissertation] Toulouse Université de Toulouse, INP, 2008.

Evon, P., Vandenbossche, V., Pontalier, P.Y., \& Rigal, L. (2007). Direct extraction of oil from sunflower seeds by twin-screw extruder according to an aqueous extraction process: Feasibility study and influence of operating conditions. Ind Crops and Prod., 26, 351359.

Jung, S. (2009). Aqueous extraction of oil and protein from soybean and lupin: a comparative study. J. Food Process Pres., 33, 547-559.

Kabirullah, M., \& Wills, R.B.H. (1981). Functional-properties of sunflower protein following partial hydrolysis with proteases. Lebensm.-Wiss Technol, 14(5), 232-236.

Kabirullah, M., \& Wills, R.B.H. (1983). Characterization of sunflower protein. J Ag Food Chem., 31(5), 953-956.

Karayannidou, A., Makri, E., Papalamprou, E., Doxastakis, G., Vaintraub, I., Lapteva, N., \& Articov, G. (2007). Limited proteolysis as a tool for the improvement of the functionality of sunflower (Helianthus annus L.) protein isolates produced by seeds or industrial byproducts (solvent cake). Food Chem., 104(4), 1728-1733. 
Kartika, I.A., Pontalier, P.Y., \& Rigal, L. (2006). Extraction of sunflower oil by twin screw extruder: Screw configuration and operating condition effects. Bioresource Technol., 97(18), 2302-2310.

Latif, S., \& Anwar, F. (2013). Aqueous enzymatic sesame oil and protein extraction. Food Chem., 125, 679-684.

Mantese, A.I., Medan, D., \& Hall, A. (2006). Achene structure, development and lipid accumulation in sunflower cultivars differing in oil content at maturity. Ann Bot., 97 , 999-1010.

Moura, J., Campbell, K., Mahfuz, A., Jung, S., Glatz, C.E., \& Johnson, L. (2008). Enzymeassisted aqueous extraction of oil and protein from soybeans and cream de-emulsification. J Am Oil Chem Soc., 85(10), 985-995.

Moura, J., \& Johnson, L.A. (2009). Two-stage countercurrent enzyme-assisted aqueous extraction processing of oil and protein from soybeans. J Am Oil Chem Soc., 86(3), 283289.

Rosenthal, A., Pyle, D.L., Niranjan, K., Gilmore, S., \& Trinca, L. (2001). Combined effect of operational variables and enzyme activity on aqueous enzymatic extraction of oil and protein from soybean. Enzyme Microb Technol., 28, 499-509.

Rouilly, A., Orliac, O., Silvestre, F., \& Rigal, L. (2003). Thermal denaturation of sunflower globulins in low moisture conditions. Thermochim Acta., 398(1-2), 195-201.

Sineiro, J., Dominguez, H., Nunez, M.J., \& Lema, J.M. (1998). Optimization of the enzymatic treatment during aqueous oil extraction from sunflower seeds. Food Chem., 61(4), 467474.

Tabtabaei, S., \& Diosady, L.L. (2013). Aqueous and enzymatic extraction for the production of food grade proteins and industrial oil from dehulled yellow mustard flour. Food Res Int., 52, 547-556.

Vankova, N., Tcholakova, S., Denkov, N.D., Ivanov, I.B., Vulchev, V.D., \& Danner, T. (2007). Emulsification in turbulent flow: 1. Mean and maximum drop diameters in inertial and viscous regimes. J Colloid and Interface Sci., 312(2), 363-380.

Zhang, Y. L., Li, S., Yin, C. P., Jiang, D. H., Yan, F. F., \& Xu, T., (2012). Response surface optimisation of aqueous enzymatic oil extraction from bayberry (Myrica rubra) kernels. Food Chem., (135), 304-308. 


\section{Figure captions}

448 Figure 1- (a) Image of native sunflower cotyledon cells. Protein bodies are dark blue globules <

$44920 \mu \mathrm{m}$ in length. Oil bodies fill the cytoplasmic space between protein bodies, 40X

450 magnification. (b) Image of tissue after extrusion with features indicated: DC, region of

451 disrupted cotyledon cells; S, region of intact sclerenchyma cells; SC, seed coat, 10X

452 magnification.

453

454 Figure 2- Images of sunflower meal residue after extraction: (a) AEP Coarse layer sample 455 (extracted without enzyme) showing intact sclerenchyma cells, 40X magnification; (b) EAEP

456 coarse layer sample (extracted with cellulase) showing intact sclerenchyma cells, 10X

457 magnfication; (c) AEP fine layer sample 40X magnification (no enzyme); (d) EAEP fine layer

458 sample, 40X magnification. CO, coalesced oil; S, region of sclerenchyma cells; DC, region of 459 disrupted cotyledon cells (extracted with cellulase).

461 Figure 3- Differential scanning calorimetry profiles of sunflower meal that was extruded at $462100^{\circ} \mathrm{C}$ and then ground and meal that was pressed at room temperature and then ground.

463 Denaturation temperatures were near $150^{\circ} \mathrm{C}$ with denaturation enthalpies of $9.7 \mathrm{~J} / \mathrm{g}$ protein for 464 both treatments.

465

466

467

468

469

470

471

472

473
Figure 4- Fit tests of the multiple linear regression model for oil extraction yield, protein solubilization, and solubilization of non-lipid material using estimates determined after elimination of the insignificant effects (Table 3). E.g. predicted oil extraction yield $=0.29-$ $0.0057 * \mathrm{~S} / \mathrm{L}+0.0003 *$ protease $+0.038 *$ agitation $+0.014 *$ cellulase $+0.018 * \mathrm{~S} / \mathrm{L} *$ protease. Actual values are plotted against predicted values overlaid on a line of a slope of one. Response mean values are shown as horizontal dashed lines. Prediction intervals are indicated by dashed lines on either side of the line of the slope of one. 
FIGURES

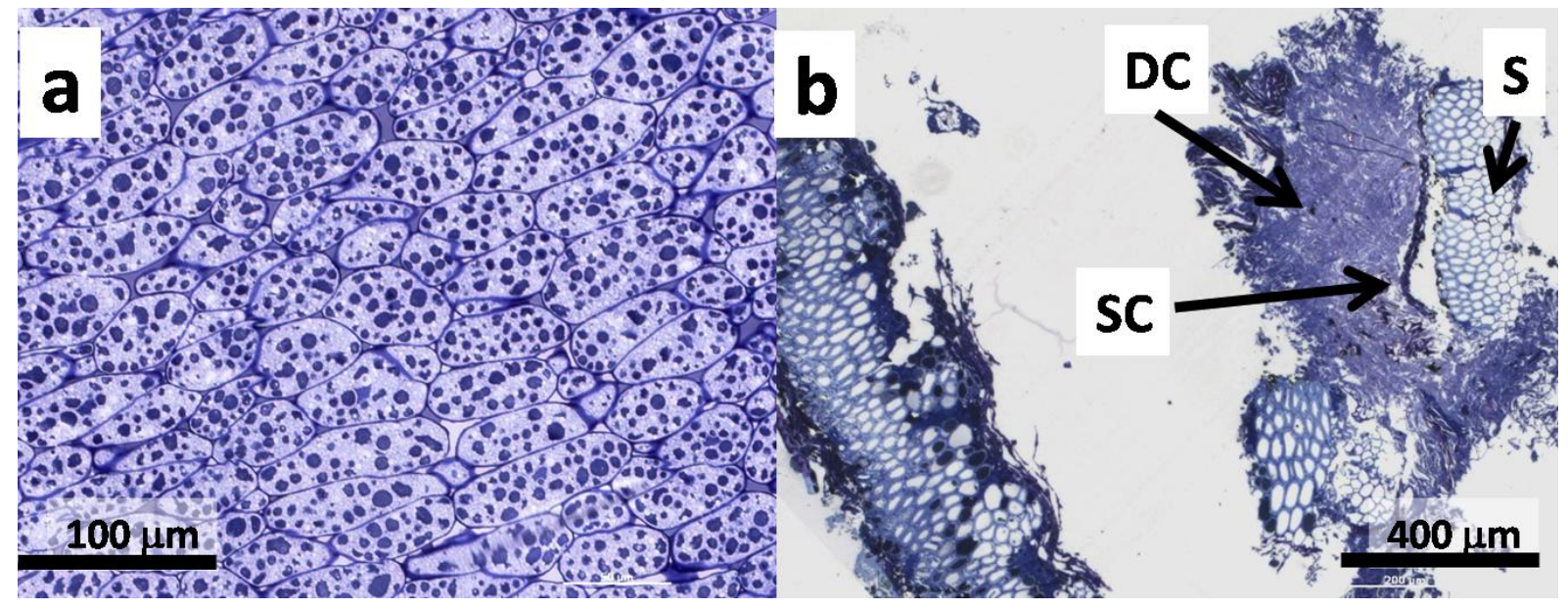

Figure 1 


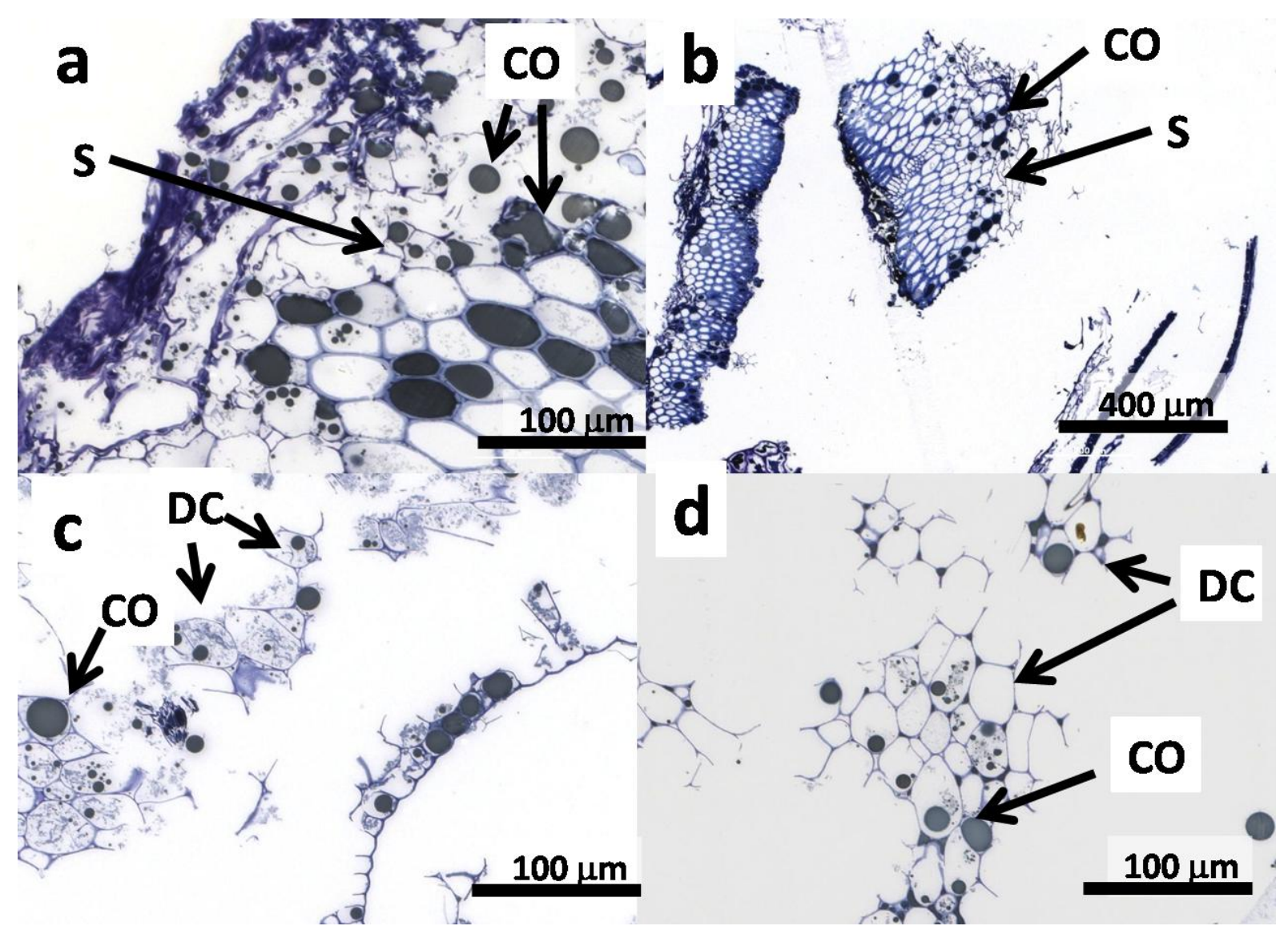

Figure 2 


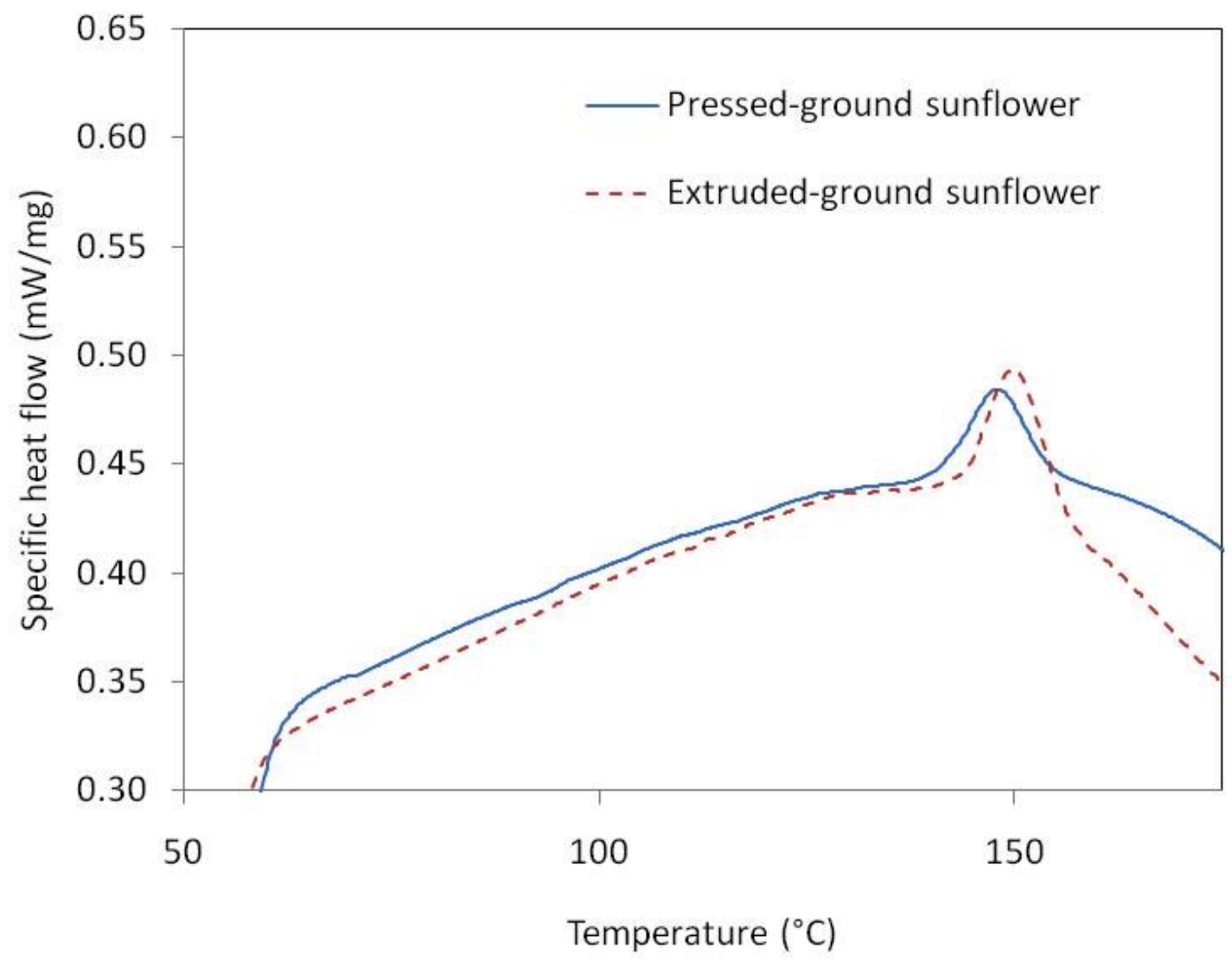

Figure 3 


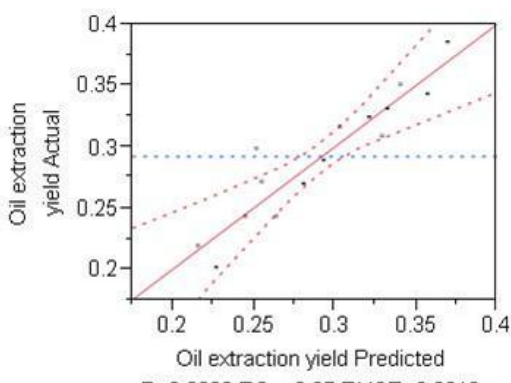

$\mathrm{P}=0.0003 \mathrm{RSq}=0.87 \mathrm{RMSE}=0.0219$

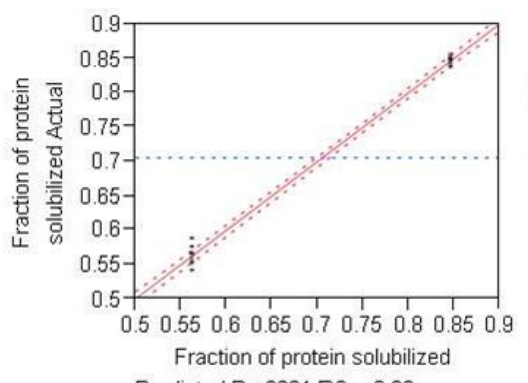

Predicted $P<.0001 \mathrm{RSq}=0.99$ RMSE $=0.0112$

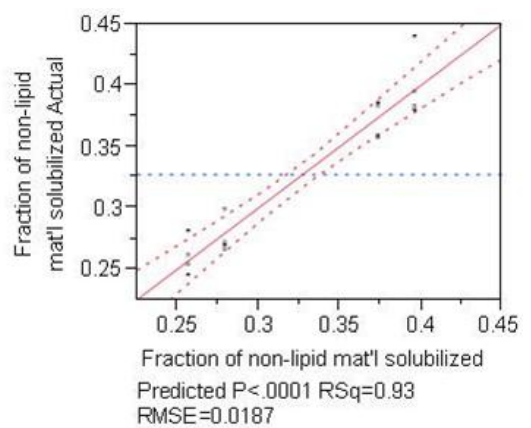

RMSE $=0.0187$

Figure 4 